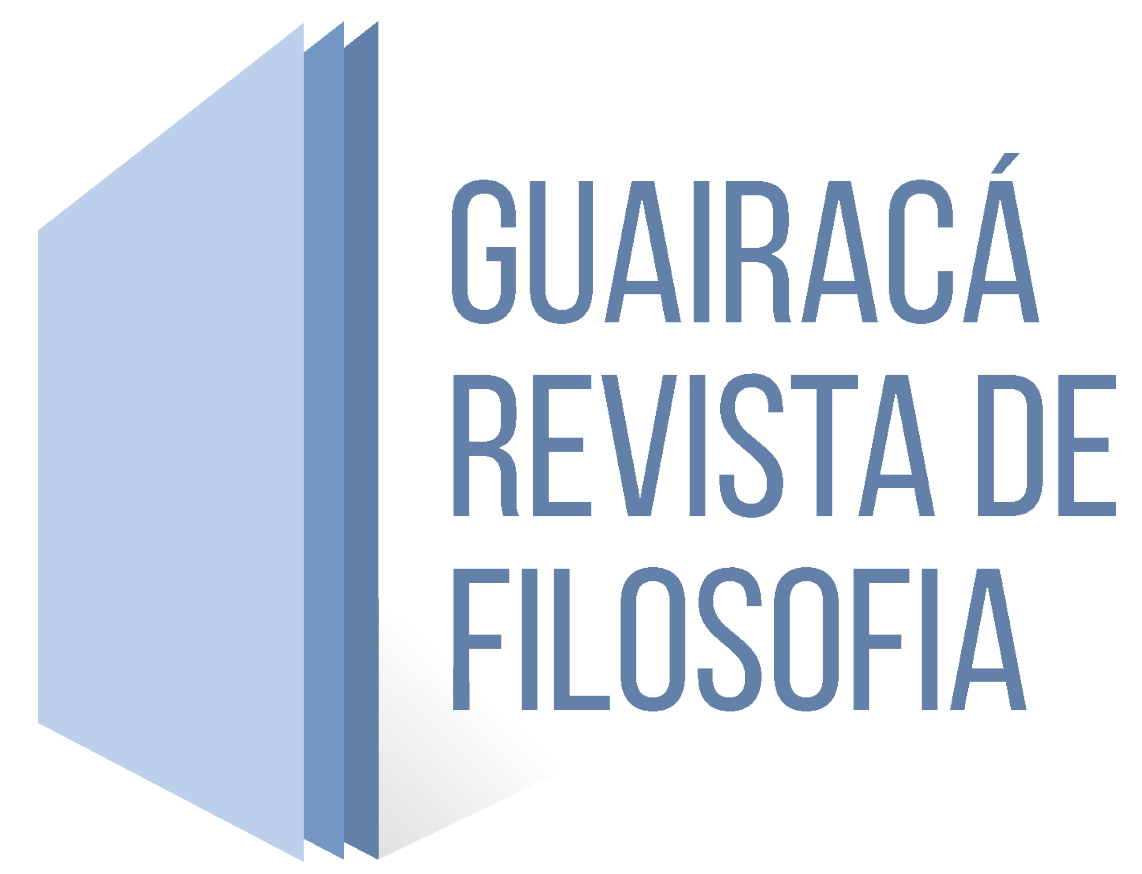

\title{
ENSAIOS METAMÓRFICOS DO TRANSCAPITALISMO PÓS-HUMANO. APONTAMENTOS REFLEXIVOS SOBRE O IDEÁRIO TRANSHUMANISTA
}

Resumo: Neste artigo, temos a pretensão de oferecer a tese segundo a qual o transhumanismo vem se colocando na atualidade como um campo decisivo para o marxismo e campo de batalha privilegiado para a teoria crítica no século XXI, essencialmente pela razão de ser uma "área do saber" escassa da participação de teóricos deste âmbito, para a qual intentamos oferecer possíveis indicativos de nossa contribuição. Para fundamentar esta proposta, veremos que o tema do transhumanismo traz consigo alguns dos problemas detectados por Adorno em suas polêmicas com Walter Benjamin, acerca do problema da aura referente a relação entre sociedade e natureza. A aura será articulada por nós à questão da permanência do poder da natureza sobre a sociedade; remeteria à possibilidade de transcender a natureza, mas que também se manifestaria na forma do poder dominador que prolongaria a natureza no interior da sociedade. Para tanto, faremos um breve percurso das linhas teóricas e políticas do debate transhumanista e, por fim, concluiremos que a ausência de um debate marxista neste meio coincide com alguns dos investimentos da chamada transburguesia, que permanece intocado por alguns ideólogos deste debate e que possivelmente gestaria os ensaios metamórficos do transcapitalismo pós-humano.

Palavras-chave: Transcapitalismo. Transhumanismo. Teoria Crítica.

1. Universidade Federal de Juiz de Fora - UFJF. E-mail: victor.rotciv_@hotmail.com 


\title{
METAMORPHIC ASSAYS OF POST-HUMAN TRANSCAPITALISM. REFLECTIONS ON THE TRANSHUMANIST IDEAL.
}

\begin{abstract}
In this article, we have the pretension to offer the thesis according to which transhumanism has been putting itself in the present time as a decisive field for the Marxism and battlefield privileged for the critical theory in the 21st century, essentially for the reason of being an "area of knowledge" the participation of theorists of this scope, for which we try to offer possible indications of our contribution. To substantiate this proposal, we will see that the theme of transhumanism brings with it some of the problems detected by Adorno in his controversies with Walter Benjamin about the aura problem regarding the relationship between society and nature. The aura will be articulated by us to the question of the permanence of the power of nature over society; would refer to the possibility of transcending nature, but would also manifest itself in the form of the dominating power that would prolong nature within society. In order to do so, we will briefly review the theoretical and political lines of the transhumanist debate and, finally, conclude that the absence of a Marxist debate coincides with some of the investments of the so-called trans-bourgeoisie, which remains untouched by some ideologues of this debate and possibly the metamorphic essays of post-human transcapitalism.
\end{abstract}

Keywords: Transcapitalism. Transhumanism. Critical Theory.

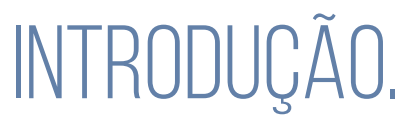

A obra de Adorno \& Horkheimer; Dialética do Esclarecimento, publicada em 1944, pode ser entendida basicamente como um amplo esforço por demonstrar que mito e esclarecimento não são figuras conceituais opostas entre si, mas que se aproximam dialeticamente em virtude da forma com que o mito, historicamente já em sua origem, portanto, contém traços de esclarecimento inerentes e que este, ao reivindicar uma superação do primeiro, acabou por se transformar em uma nova mitologia, cuja circunstância histórica paradigmática redundaram no fascismo e na indústria cultural. Não pretendemos oferecer neste trabalho uma contextualização teórica dos autores em tela, assim como de um aporte dos desdobramentos analíticos que levaram estes autores a estabelecer o sentido desta conclusão referente em suas condicionantes particulares. 
Primeiramente, o transhumanismo pode ser entendido, em síntese, como um amplo movimento filosófico, cultural e político, que retoma algumas das tradições de pensamento que de algum modo apresentaram uma transformação revolucionária do ser humano e de suas capacidades. Destaca-se que desde o advento do Iluminismo, a ideia de que a condição humana poderia ser melhorada através da razão, da ciência e da tecnologia vem sendo retomada pelos defensores do transhumanismo, partidários do aperfeiçoamento humano através dos avanços científicos e tecnológicos.

Anualmente se reúnem filósofos, escritores de ficção, artistas e sociólogos de diversas partes do mundo para debaterem questões que versam sobre o melhoramento humano, onde as mais avançadas tecnologias em sua ampla acepção; como a biotecnologia, pesquisas em Inteligência Artificial (IA), etc., são consideradas também como riscos de abuso por parte das descobertas que trazem. Em $2016 \mathrm{em}$ Madrid, Espanha, por exemplo, aconteceu a $8^{\circ}$ Conferência; "Mas allá del humanismo: Estudios Posthumanistas y tecnologias del control", ${ }^{2}$ onde se discutiram sob diversas perspectivas o tema em questão. ${ }^{3}$

Um traço peculiar, porém, da totalidade das análises apresentadas, tem sido a difusa fundamentação teórica e política da qual partem os analistas do movimento. Configurando numa pluralidade de perspectivas diversas, certas soluções extremamente variadas a toda classe de problemas suscitadas pelo debate que anunciam. Mas uma coisa se pode destacar diante dessa variedade relativa, que é o fato de que encaram o problema do desenvolvimento desigual das sociedades políticas no marco dos avanços tecnológicos a partir de soluções individualistas, que não colocam de maneira alguma o problema do capital como relação social de produção entre os sujeitos.

Dentro do escopo teórico e político do movimento como um todo, destacam-se principalmente os vínculos majoritariamente democráticos de matriz liberal-social e também vinculados ao liberalismo progressista (HUGHES, 2002) social democrata. Algumas linhas se diferenciam desta abordagem e defendem que o transhumanismo pode ser assimilado como desdobramento da religião cristã e muçulmana. Porém, muitos se voltam a Escola Austríaca para construírem suas filosofias políticas, assim como da economia colaborativa, etc., (Idem)

2. Maiores informações acerca do evento e sua programação, organizado pela equipe Metabody, ver em: http://metabody.eu/es/beyondhumanism2016/ Acesso em 15/10/2018

3. Exemplar a este respeito foi a coletânea de estudos publicadas em Madrid no ano anterior, em 2015, cujo título; "El mejoramiento humano; avances, investigaciones y reflexiones éticas y políticas", publicado pela Editora Comares e organizado pelos editores César Ortega, Andrés Richart, Víctor Páramo e Christian Ruíz, reúne diversos artigos, ensaios, debates e estudos acerca do transhumanismo, na tentativa de situá-lo como "área do saber" científico contemporâneo, que porém se mostram fetichistas por não colocar em questão o capitalismo como modo de produção, a propriedade privada da tecnologia subsumida ao capital, etc., 
A esta última corrente se estruturou o extropianismo, - um ponto de reversão da entropia termodinâmica -, cuja situação, segundo Cabrera \& Cardoso, se "encontra na gênese mesma do que atualmente é o transhumanismo, incluindo dentro de suas construções o conceito de ordem espontânea, e se baseia na autogestão e na modificação da mente e do corpo dos seres humanos." (CARDOSO. J. \& CABRERA. T. 2014. p. 66. Tradução nossa). Paralela a estas correntes existem outras, que nos limitaremos aqui a apenas pontuá-las genericamente, como por exemplo, ativistas das esquerdas pós-modernas, partidários da teoria Queer; do feminismo futurista; do afrofuturismo; ciberpunks e biopunks, ativistas de software livre; pela renda básica universal etc., a maior parte dos mesmos se consideram anticapitalistas, porém de modo algum no sentido marxista do termo. Há também o transhumanismo da singularidade, defensores da união entre máquinas e organismos biológicos para alcançarem o que chamam de pós-biologia. (Idem) Tecnogaianismo, que seriam os transhumanistas ecologistas; também há pós-humanistas que supõe ser o transhumanismo apenas um momento de transição entre o humano e pós-humano e, por fim, o transhumanismo de tendência fascista, que mescla o Übermacht nietzschiano e algumas artes futuristas como a do escritor Marinetti criador do "manifesto do futurismo" em 1909. Este último possui traços de nacionalismo étnico, incluindo o racismo eugenista na compreensão do movimento. Este movimento vem sendo impulsionado pelo neofascista francês Alain de Benoist. James Hughes salienta em seu artigo intitulado; "The politcs of transhumanism 2.0", que

\begin{abstract}
Desde o surgimento da cibercultura, o meme technopeu encontrou um meio natural, e sofreu mutações e cruzamentos furiosos com ideologias políticas. Uma de suas manifestações recentes adotou o rótulo de "transumanismo" e, dentro dessa tenda ideológica escassamente povoada, mas ampla, muitos híbridos proto-ideológicos estão se agitando. Muitas proto-políticas transumanistas são claramente o produto do libertarianismo elitista, masculino, norte-americano, limitando sua capacidade de responder às preocupações por trás do crescente movimento neoludita, como a equidade e a segurança das inovações. Comprometidos apenas com a liberdade individual, os transhumanistas libertários têm pouco interesse em construir a solidariedade entre "póshumanos" e "normais", ou na elaboração de projetos tecnoputânicos que possam inspirar amplos movimentos sociais. (HUGHES. J. 2002. Tradução nossa. Grifo nosso. p. 2)
\end{abstract}

Este traço é ratificado pelo líder do partido transhumanista Zoltan Istan, que concorreu ao governo da Califórnia, em 2016, que define o movimento

Como um campo radical da ciência que objetiva transformar os humanos, por falta de melhor termo, em deuses. [...] O corpo humano é uma peça medíocre (sic) devido a nossas atuais possibilidades nesse nosso universo material. Nossa biologia nos limita severamente. Como espécie, estamos longe de ser completos, e isto é inaceitável. A biologia é para as bestas, não para os futuros transumanistas. [...] Em comparação com os seres humanos, os ratos têm narizes melhores para cheirar. Os pombos têm olhos mais agudos para ver. Crocodilos podem correr mais rápido. Minhocas podem sobreviver debaixo 
d'água por mais tempo. Baratas podem suportar temperaturas muito mais frias. Os seres humanos são melhores apenas no raciocínio. No entanto, os computadores já podem bater o melhor de nós no xadrez, matemática e, recentemente, o sublime jogo Go. E os robôs que fizemos são muito mais fortes do que nós, podem aguentar maiores perigos e podem voar pelo espaço interestelar sem nós. ${ }^{4}$

A ausência de perspectivas marxistas neste debate talvez sejam sintomas da urgência de sua apropriação crítica. Tendo em vista estarem em disputa determinados projetos políticos, os quais sendo pautados sobre critérios individualistas de sujeitos isolados, acabam por tomar como fetiche os avanços tecnológicos e científicos do tempo presente e futuro. Por consequência, acabam por modular a longo prazo os traços objetivos de suas pautas através de critérios instrumentais, em vista do qual não parecem entender do que exatamente estejam falando quando pensam a tecnologia e suas funções.

[...] O que não se diz é que o terreno no qual a técnica conquista seu poder sobre a sociedade é o poder que os economicamente mais fortes exercem sobre a sociedade. A racionalidade técnica hoje é a racionalidade da própria dominação. Ela é o caráter compulsivo da sociedade alienada de si mesma. (ADORNO \& HORKHEIMER. 2014. p. 99-100. Grifo nosso)

Ora, um dos traços ideológicos patentes no movimento transhumanista, dentre a diversidade de orientações políticas que reivindicam, se dá precisamente na forma com que pretendem "solucionar" os desafios colocados pelos avanços tecnológicos, recorrendo ao conceito de natureza humana, sem distinguir os modos históricos de apropriação desta. Assim, acabam por idealizar os processos sociais em que incidem estas tecnologias. ${ }^{5}$ Afinal, absolutamente ninguém, - com exceção dos "feiticeiros" 6 de Silicon Valley e seus investidores multibilionários, - pode antecipar com exatidão a finalidade das pesquisas transhumanistas nas instalações secretas de

4.Fonte:https://www.huffingtonpost.com/zoltan-istvan/transhumanism-and-our-out_b_9749138.html (Acesso em 28/09/2018. Tradução nossa. Grifo nosso)

5. “O Google engoliu quase todas as empresas de robótica e aprendizado de máquina. Ele comprou a Deep Mind por US \$ 650 milhões e construiu a equipe do Google Brain para trabalhar com inteligência artificial. Também contratou Ray Kurzweil, o futurista que previu que os humanos estão a 28 anos da "singularidade" o momento em que a capacidade da superinteligência artificial supera a inteligência humana, e os humanos se fundirão com a inteligência artificial para criar seres híbridos. Ray Kurzweil prevê que até 2030, seremos ciborgues. Nano robôs do tamanho das células sanguíneas curam nossos corpos por dentro - conectando-nos ao neo-córtex sintético na nuvem e à realidade virtual e aumentada. "Seremos mais engraçados, mais musicais, mais sábios", disse." Fonte: http://www.kurzweilai.net/vanity-fair-elon-musks-billion-dollar-crusade-to-stopthe-ai-apocalypse (Tradução nossa. Acesso em 11/10/2018)

6. O uso deste termo em específico, ainda que entre aspas, pretende apontar para a forma como geralmente são recebidas algumas das inovações tecnológicas apresentadas por Silicon Valley, as quais fazem questão de se portarem como tais quando oferecem ao público algumas de suas criações, a exemplo do primeiro robô equiparada com Inteligência Artificial (IA), Sofia, onde se pode notar certa "aura" revestindo sua exposição. Ver em: https://www.youtube.com/watch? $v=5 n C V E 76 L q Z Q$ (Acesso em 15/10/2018) 
seus laboratórios de pesquisa. Em todo caso, a título de exemplo, alguns protótipos já estão acessíveis no Youtube;

Ora, não faltarão razões para designarmos estes autômatos como o "Outro" por excelência. Com a ressalva de que apareça como prótese inteligente, trazendo consigo o símbolo arcaico do divino encarnado na forma do Mesmo; espécie de deus ex machine, ou mero modelo espectral de adoração religiosa do humano reificado, como insinua Baudrillard;

De todas as próteses que balizam a história do corpo, o duplo é sem dúvida a mais antiga. Mas o duplo não é uma prótese; é uma figura imaginária que - tal como a alma, a sombra, a imagem no espelho - persegue o sujeito como seu outro, faz com que seja ao mesmo tempo ele mesmo e não se pareça nunca também, que o persegue como uma morte sutil e sempre conjurada. Nem sempre, porém; quando o duplo se materializa, quando se torna visível, significa morte iminente. (BAURDRILLARD. J. 1990. p. 121)

Porém, qual seria a relação entre a estrutura desse "outro" tornado visível e a mistificação de algumas de suas capacidades robóticas no âmbito destas investigações transhumanistas, em que pesem os investimentos de capitais no ramo do chamado "melhoramento humano"?

\begin{abstract}
Serviço de intranet? Verifica. Moto autônoma? Verifica. Tecnologia de carro sem motorista? Verifica. Obviamente, o próximo projeto lógico para um engenheiro de sucesso do Vale do Silício é estabelecer uma organização religiosa que adore a IA. Anthony Levandowski, que está no centro de uma batalha legal entre a Uber e a Waymo, do Google, estabeleceu uma corporação religiosa sem fins lucrativos chamada Way of the Future, de acordo com registros oficiais descobertos pela Backchannel da Wired. A surpreendente missão de Way of the Future: "Desenvolver e promover a realização de uma Divindade baseada em inteligência artificial e através da compreensão e adoração da Trindade, que possam contribuir para a melhoria da sociedade. ${ }^{8}$
\end{abstract}

É interessante notar que em 2002, o fundador do Paypal, Peter Thiel, tenha vendido sua companhia, o eBay, por nada menos que 1.5 bilhões de dólares estadunidenses, e tenha investido uma grandiosa quantia de dinheiro em investimentos no ramo transhumanista da indústria antienvelhecimento. ${ }^{9}$ Desde então,

7. A Boston Dynamics vem divulgando uma série de inovações no âmbito da robótica equipada com (IA). Ver em: https://www.youtube.com/watch?v=vjSohj-Iclc (Acesso em 14/10/2018)

8. “Benek argumenta que a IA avançada é compatível com o cristianismo: “É apenas outra tecnologia que os humanos criaram sob a orientação de Deus, que pode ser usada para o bem ou para o mal." [...] "Eu penso totalmente que a IA pode participar nos propósitos redentores de Cristo", disse ele, garantindo que está imbuído de valores cristãos." Fonte: https://www.theguardian.com/technology/2017/ sep/28/artificial-intelligence-god-anthony-levandowski (Tradução nossa. Grifo nosso. Acesso em $16 / 10 / 2018)$

9. “Em 2002 o fundador do Paypal, Peter Thiel vendeu sua empresa eBay por 1.500 bilhões de dólares. Desde então, se dedicou a dirigir vários fundos de investimento com um único objetivo; esquivar da morte. Igualmente a outros multimilionários, acredita que a indústria antienvelhecimento é um negócio 
muitos outros capitalistas transhumanistas vem se dedicado a "superar sua própria morte", algo como um esforço por se transformarem em porta-vozes das tendências postas no movimento. Com efeito, certas pesquisas genético-moleculares estariam na pauta dessa burguesia.

As investigações no ramo do código genético apontam precisamente para um futuro lastreado pela confusa duplicação do humano na forma dos clones, como divulgado pelo cientista chinês He Jiankui, que anunciou em "tom messiânico", ter conseguido criar os primeiros bebês geneticamente modificados. ${ }^{10}$

\begin{abstract}
Sonho de uma eterna gemelidade que substitua a procriação sexuada, a qual está ligada à morte. Sonho celular de cissiparidade, a forma mais pura do parentesco, pois permite prescindir do outro e ir do mesmo ao mesmo. Utopia monocelular que, por via genética, faz os seres complexos acederem ao destino dos protozoários. (BAUDRILLARD. J. 1990. p. 122)
\end{abstract}

Outra situação interessante, foi quando o cirurgião italiano Sergio Canavero, apresentou em 2016 a possibilidade de se realizar o primeiro transplante de cabeça do mundo. Ora, não é difícil supor que muitos bilionários anciãos telefonaram para Canavero mostrando-se interessados em serem seus pacientes. ${ }^{11}$ O que dizer dos objetivos visionários com que Bill Maris, chefe da Google Ventures, que anunciou investimento de 425 milhões de dólares ao ano para projetos de reversão do envelhecimento? Aparentemente, o transhumanismo apareceria, por

inovador. Segundo os dados da consultora Global Industry Analysts, o setor move algumas somas de dinheiro próximas aos 60.000 milhões de euros ao ano, em que pese a que muitos de seus produtos são ainda intangíveis e invendíveis. Pouco importa, o entusiasmo em torno das futuras conquistas desta indústria é maiúsculo e não apenas porque seus promotores pensam ganhar muitíssimo dinheiro, senão também porque, como asseguram todos - com um discurso que beira ao messiânico - os avanços que trará consigo a biotecnologia suporão uma revolução sem precedentes na história da humanidade. Estes empresários investem milhões de dólares com a certeza de que poderão reconstruir, regenerar e reprogramar os órgãos vitais e, inclusive, o DNA das pessoas, para que vivamos (ou melhor, vivam) mais e melhor. (Ayuso. 2015. In; https://www.elconfidencial.com/alma-corazon-vida/2015-04-24/la-inmortalidad-es-el-sueno-de-losnuevos-filantropos_725677/ Acesso em 16/10/2018. Tradução nossa. Grifo nosso)

10. “Foi aberta uma caixa de Pandora. É de uma irresponsabilidade colossal. Não é uma edição para curar. É uma melhora genética. O passo seguinte é uma eugenia total. Dirão aos pais: “O que os senhores desejam?" O veto foi levantado, que é o que não queríamos que acontecesse, mas aconteceu onde sabíamos que ocorreria: na China. É preciso dizer claramente que essa experiência é ilegal em nosso país e além disso é ilegal em muitos outros países, incluindo os EUA e o Reino Unido, onde é possível a edição genética de embriões em pesquisa, mas não sua implementação em uma mãe", disse Lluís Montoliu." Fonte:https://brasil.elpais.com/brasil/2018/11/26/ciencia/1543253567_659329. html?\%3Fid_externo_rsoc=FB_BR_CMEfbclid=IwAR0jhxojZ-AjeYb7gZao9ZICHuC9nbQbtLUPSeJ19Rc XSY3amoSp-ashrnM (Acesso em 30/11/2018)

11. "Além de usar a técnica para ajudar pessoas com doenças severas ou paralisia corporal, o Dr. Canavero prezê que as pessoas poderiam, no futuro, obter novos corpos saudáveis à vontade, prolongando suas vidas indefinidamente, com uma cabeça cada vez mais velha nos ombros jovens." (NAISH. John. 2016. Tradução nossa. Grifo nosso. Acesso em 18/10/2018. In. https://www.dailymail.co.uk/news/article-3412928/The-reallife-Doctor-Frankenstein-plotting-human-HEAD-transplants-Controversial-neurosurgeon-wants-paralysedpatient-new-body.html) 
um lado, como uma tentativa de "refundação do projeto de esclarecimento", e, por outro, remete ao princípio de atrofia da aura, de perda de uma antiga forma de contato com a natureza, mas que representaria, como efeito, um processo de libertação? ${ }^{12}$ Veremos.

Outro exemplo importante relatado por Ayuso em artigo citado, é o de Dmitry Itskov fundador do New Media Starts e da iniciativa 2045, dedicada a desenvolver o que denomina de imortalidade cibernética. O planejamento consiste em produzir ciborgs inteligentes capazes de armazenar a consciência humana depois da morte orgânica, permitindo viver uma vida para além dos limites impostos pela natureza. Observa-se que o ascetismo quase religioso de Itskov e Thiel, por exemplo, enquanto capitalistas transhumanistas declarados, consiste em militar pela causa transhumanista por acreditarem "ser possível e necessário, eliminar o envelhecimento, ou inclusive a morte, assim como exceder os limites normais estabelecidos pelas restrições do corpo físico. " (Ayuso. 2016a) Não por acaso o fundador da companhia de software Oracle Corporation, o senhor Larry Ellison, doou cerca de 400 milhões de dólares para investigações deste quilate. (Idem). O ideário transhumanista que revestem estes investimentos da burguesia transhumanista, sinaliza um período de fortes avanços tecnológicos nas investigações sobre "melhoramento humano", e conduz que esteja sendo guiado pelo compromisso esclarecido de se libertarem dos limites da própria morte.

Todavia, este progresso parece herdar os traços míticos na Aufklärung, em que pese o desejo impenitente em não mais serem eles considerados como apenas simples pessoas mortais; o movimento esclarecido do transhumanismo contemporâneo converge com os interesses da burguesia em seu esplendor progressista, ao mesmo tempo em que patenteia o núcleo mítico de sua progressão histórica. Pois vem especulando se converter em mais do que apenas uma classe que necessita controlar e expandir o desenvolvimento da biologia sintética e da neurociência, mas também de se colocar como portadores legítimos desse processo. O transhumanismo contemporâneo acabaria por aparecer mais como um elemento visionário de um transcapitalismo tendencialmente protagonizados no presente séc. XXI por essa burguesia hightech do que qualquer outra coisa, portanto.

Para que possamos demonstrar esta vinculação, temos de retomar a questão em Adorno e Benjamin, acerca do problema da técnica versus perda da aura no intuito de elenca-las sobre a perspectiva de nosso trabalho até aqui. Mas antes deste procedimento, falemos um pouco mais a respeito dos capitalistas transhumanistas

12. "Se me perguntas se é possível viver até os 500 anos a resposta é sim. " Assegurou o diretivo, neurologista de formação, em uma relevadora entrevista para a Bloomberg Markets, em 2015. Maiores informações, ver em: https://www.bloomberg.com/news/articles/2015-03-09/google-ventures-bill-marisinvesting-in-idea-of-living-to-500 (Tradução nossa. Acesso em 18/10/2018) 
e seus investimentos em biotecnologia. Afinal, que esperam desses resultados no curto prazo?

Investem pela razão de serem tomados por algum sentimento altruísta que possa prometer universalizar o acesso aos bens com os quais a humanidade inteira poderia se beneficiar, ou a rigor, se apoiam nesse ideário transhumanista do mito da imortalidade e ressurreição como contraparte ideológica do individualismo neoliberal levado por fim ao paroxismo?

Uma vez que ascende a volúpia prometeica de domínio e de expansão universal das forças produtivas, quais agenciamentos estariam na "ordem do dia" para o século XXI sobre este aspecto, já que se trata da formação de uma "identidade trans-humana" por vir? Ademais, qual a modalidade da contradição entre humanos "normais" e outros "melhorados" residira neste princípio constitutivo da emergência de uma "nova diferença" no marco da identidade ocidental, reiterada pelo discurso transhumanista?

Para qualificar as características dos povos não-ocidentais, distinguindo-os daquilo que constitui, alternadamente, a beleza e a pobreza da mentalidade europeia, o filósofo hindu Panikkar usa os termos "antropocêntrico" e "cosmocêntrico". É uma distinção fértil, dela deriva tudo aquilo que se pode afirmar a respeito do homem ocidental, que se coloca no centro do universo, ao empreender a aventura do individualismo inspirado em Prometeu. Ele tem uma concepção de vida linear e não cíclica; sente necessidade de conquistar a natureza e os demais seres humanos, ao invés de cultivar a harmonia com o meio ambiente. Dá prioridade ao fazer e ao ter, ao invés de ressaltar o ser. [...] o homem só passou a conceber uma relação com a natureza em termos de dominação, aspirando permanentemente à apropriação da onipotência dos deuses. (VERHELST. T. 1992. p. 47-8. Grifo nosso)

Ao que aparece, por outro lado, não resta a menor dúvida que os capitalistas transhumanistas estejam muito mais interessados em se tornarem imortais, do que dispostos a resolverem a desigualdade social no acesso a bens tecnológicos decisivos. Por essa razão, estes capitalistas podem até mesmo admitir que a humanidade poderá "colher os frutos" da bonança por vir, mas desde que sejam eles os primeiros a se elevarem a figuras divinais sobre a "terra deles". Pode-se dizer, desse modo, que a função ideológica mais visível do movimento transhumanista, consiste em converter em fetiche estes mesmos "ensaios metamórficos" da parte da burguesia high tech; já que enquanto pensam o processo, quem pratica sua filosofia são os talibãs de Silicon Valley.

Consequentemente, para estes, a filosofia transhumanista apareceria como a realização de seus impulsos, desde a emergência histórica de sua "classe virtual" até o presente no futuro, do qual se consideram a si mesmos os únicos herdeiros e, portanto, os "proprietários consagrados da vida e da morte para todo sempre". Personificam as formas alienadas da produção revertendo-as enquanto súmula do 
esclarecimento nessa eterna busca por realizar o mito do "eterno retorno do mesmo", eliminando qualquer vestígio de diferença, dessa vez colocada sobre os marcos da relação entre humanos "melhorados biotecnologicamente" e todos os outros, nessa reiteração do conflito basal da identidade e sua alteridade. De tal maneira que a filosofia transhumanista vem a colocar em questão certa abordagem acerca das inovações tecnológicas, pressupondo que os investimentos massivos de capitais nas mesmas irão favorecer um mercado de melhoramento humano garantidor de seu acesso democrático e usual, portanto. Este traço ideológico é patente na maioria das vertentes que reivindicam este estatuto, uma vez que em sua generalidade teórica ainda não colocam em questão ao capital como relação social entre as pessoas, e por sua vez, delegam a tecnologia a uma figura abstrata, isenta de determinações.

Porém, outras questões estãoemjogonesteavançotecnológico protagonizado por investidores transhumanistas, como apontam alguns dos possíveis efeitos dessa aparente "libertação humana", por exemplo. Segundo nosso parecer, há uma série de nexos sociais que sustentam a retomada deste debate na contemporaneidade, que, porém, são em sua grande totalidade desprezados. Por não oferecerem uma análise materialista do fenômeno, acabam por tomar o avanço tecnológico que permitem suas elucubrações, como processos naturais e, que, portanto, reproduzem como um claro sintoma de fetiche.

[...] O materialismo tosco dos economistas, de considerar como qualidades naturais das coisas as relações sociais de produção dos seres humanos e as determinações que as coisas recebem, enquanto subsumidas a tais relações, é um idealismo igualmente tosco, um fetichismo que atribui às coisas relações sociais como determinações que lhes são imanentes e, assim, as mistifica. (MARX. K. 2011. p. 575. Grifo nosso)

Por detrás destes ensaios teóricos aparentemente suspensos da realidade que pretendem responder, o que vem ocorrendo realmente é um desenvolvimento sem precedentes das pesquisas no âmbito da Inteligência Artificial (IA); Internet das Coisas (IoT); do Big Data e afins, no que se denomina hoje de "Quarta Revolução Industrial. "13 Não entraremos na seara acerca do contexto histórico deste último 13. No ano de 2011, o governo alemão investiu mais de 200 milhões de dólares para criação da plataforma "Industrie 4.0" (Comissão Europeia, 2017). Os EUA, desde 2014, tem investido cerca de 70 a 110 milhões de dólares ao ano em "manufatura avançada". Ver em: https://www.manufacturing.gov/ funding. (Acesso em 16/10/2018) O Japão prometeu até 2020 investimentos na casa dos 700 milhões de dólares para seu $5^{\underline{o}}$ Plano de Ciência e Tecnologia. Tal como a SoftBank japonesa que destinou 28 bilhões de dólares para o seu Vision Fund, um fundo voltado para investimentos em alta tecnologia. Ver em: https://money.cnn.com/2017/10/20/technology/softbank-masayoshi-son-vision-fund-technology/ index.html A China, sob o slogan "Made in China 2025", direcionou incialmente 24 bilhões de dólares para fundos destinados à inovação (Wübbeke et al. 2016). A empresa Apple anunciou investimentos de cerca de 4 bilhões de dólares nos EUA para contribuir com sua "manufatura avançada", ver em: https://www.apple.com/newsroom/2018/01/apple-accelerates-us-investment-and-job-creation/ (Acesso em 18/10/2018. Tradução nossa) Tais exemplos reforçam a tese segundo a qual o transhumanismo se apresenta hoje carregado de tensões de ordens econômicas e políticas entre as nações mais avançadas. 
ponto, apenas salientamos a ausência dos critérios materialistas nas concepções transhumanistas, afinal;

O Big Data parece estar associado à esperança de que as "ciências" forneçam aos políticos receitas que possam ter sido negligenciadas até agora, e/ou testem a eficácia dessas receitas por meio de simulações em computador. Essa abordagem lembra um pouco a ideologia dos transumanistas, que, para resolver os problemas do mundo, estão exigindo o desenvolvimento de uma inteligência artificial que supere o ser humano e, de algum modo, o substitua como espécie. [...]. Tal desenvolvimento é consequente em uma sociedade fetichista que é demasiado cega em relação a si mesma, e que não consegue fundamentar-se a si mesma. O novo mundo inteligente, afinal, não é senão $o$ estado de exceção digitalizado, um ordenamento inteligente do estado de necessidade, que quer lidar com qualquer problema ou pseudoproblema com ainda mais segurança, ainda mais vigilância e ainda mais tecnologia digital. A digitalização é pouco mais que a reprodução da insanidade capitalista numa escala maior. (MEYER. T. 2018. p. 18 Grifo nosso)

O Big Data e a Inteligência Artificial (IA), por exemplo, vem se tornando um instrumento poderosíssimo do capital no século XXI para impor às nações sua lógica instrumental de produção e de controle social. Estas tecnologias vêm apontando uma cada vez maior capacidade de rastrear as pessoas e inclusive avaliá-las ${ }^{14}$, como constata Andrew Ng, fundador do Google Brain; que diz que "essas aplicações têm o poder de ampliar ainda mais a divisão social, onde a inteligência artificial ameaça superar o impacto de grandes empresas de tecnologia e plataformas de mídia social, enquanto os líderes autocráticos terão novas oportunidades"15.

Atualmente, em um país como a China, por exemplo, que está implantando uma vasta rede de câmeras de vigilância ${ }^{16}$ e equipando seus policiais com óculos

14. “[...] A ambição é coletar todos os fragmentos de informações disponíveis on-line sobre as empresas e os cidadãos da China em um único lugar - e então atribuir a cada um deles uma pontuação baseada em seu "crédito" político, comercial, social e legal. [...]. Aproveitando o poder da big data e a onipresença dos smartphones, comércio eletrônico e mídias sociais em uma sociedade na qual 700 milhões de pessoas vivem grande parte de suas vidas on-line, o plano também vai filtrar registros judiciais, policiais, bancários, fiscais e trabalhistas. Médicos, professores, governos locais e empresas poderiam ser avaliados pelos cidadãos por seu profissionalismo e probidade. "Fonte: https://www.independent.co.uk/news/world/asia/china-surveillancebig-data-score-censorship-a7375221.html (Tradução nossa). Acesso 01/11/2018

15. ANDREW NG, fundador do Google Brain e diretor do grupo de inteligência artificial do Baidu em uma entrevista à plataforma de imprensa Axios. Fonte: https://fr.express.live/2018/10/11/lintelligence-artificielleest-une-aubaine-pour-les-autocrates (Tradução nossa). Acesso em 01/11/2018.

16. “Na China, as câmeras e scanners que registram os rostos e movimentos das pessoas são inúmeras e diversas, pois o reconhecimento facial torna-se uma característica da vida cotidiana dos chineses. Esta tecnologia é usada por autoridades nas ruas, estações ferroviárias, estações de metrô, aeroportos, postos de fronteira, etc. Esta é uma vasta experiência em engenharia social. O objetivo é influenciar o comportamento e identificar os infratores, diz o Wall Street Journal. A videovigilância na China já representa $46 \%$ do mercado global neste setor. Na última década, o setor cresceu a uma taxa média anual de 13,3\%. Para os próximos cinco anos, esperamos um crescimento médio de dois dígitos, diz o jornal Le Temps.' Fonte. https://frexpress.live/2018/01/12/big-brother-chine-450-millions-decameras-de-surveillance-territoire-dici-2020/ (Tradução nossa). Acesso em 01/11/2018 
inteligentes, ${ }^{17}$ longe de serem apontamentos estritamente regionais, demonstram ser, grosso modo, o "modelo" positivista de aplicação e gestão da questão social nas próximas décadas em todo o mundo globalizado. Mas o que isto tem a ver com o debate transhumanista? Ora, a maioria dos mesmos sequer pontua que paralelo aos avanços tecnológicos com que se entusiasmam, é o controle das pessoas que está em questão.

Will Knight, especialista em automação do MIT Technology Review, alerta acerca da capacidade da Inteligência Artificial de manusear gravações de áudio e vídeo, tornando possível imitar literalmente as expressões faciais das pessoas cada vez mais facilmente. Tendencialmente, o desenvolvimento da Inteligência Artificial permitirá que seja ainda mais difícil distinguir "pessoas falsas" das verdadeiras, isto é, das pessoas reais, em virtude desta tecnologia em rápido avanço. ${ }^{18}$ Belo exemplo de "fusão humano-máquina".

As gravações de voz são atualmente consideradas evidentes em nossas sociedades, particularmente na jurisdição de muitos países. [...] O FaceApp, um aplicativo que pode adicionar um sorriso ao rosto de uma pessoa, mudar seu sexo, apagar suas rugas ou, ao contrário, envelhecer sua aparência e até mesmo clarear a cor da sua pele. Em ambos os casos, os algoritmos de inteligência artificial não se contentam mais em analisar dados; eles são capazes de criar conteúdo. É bem possível formar uma rede de tecnologia para ensiná-la a gerar conteúdo do zero que seja notavelmente semelhante ao alvo real. ${ }^{19}$

A Internet das Coisas também progride nesta direção, este recurso tecnológico basicamente se refere a possibilidade de conectar objetos físicos de qualquer natureza a um banco de dados, inclusive pessoas. ${ }^{20}$ Progressivamente tem sido impulsionada pelo desenvolvimento e uso massivo de sensores conectados, que muito embora estejam em seu início, certamente estão sendo idealizados por alguns dos transhumanistas que enxergam tais possibilidades tecnoputânicas como marca de uma suposta transcendência das capacidades humanas; os transhumanistas estão propondo algo novo no capitalismo?

17. "Na China, o uso de inteligência artificial é comum, e agora é a vez da polícia chinesa se beneficiar dessa tecnologia. O Wall Street Journal relata que os policiais agora estão usando óculos inteligentes com câmera e reconhecimento facial. Objetivo: identificar os perpetradores de crimes fugitivos." Maiores informações, ver em: https://fr.express.live/2018/02/09/les-policiers-chinois-ont-des-lunettes-intelligentes-qui-permettentdidentifier-les (Tradução nossa). Acesso em 28/10/2018

18. Para fins de apreciação, consultar uma demonstração desta tecnologia no programa chamado; "Face2Face: Real-time Face Capture and Reenactment of RGB Videos", disponível no Youtube; https://www. youtube.com/watch?time_continue $=113 \& v=$ ohmajJTcpNk (Acesso em 15/10/2018)

19. (KNIGHT. W. 2017. Fonte: https://www.technologyreview.com/s/604270/real-or-fake-ai-is-making-itvery-hard-to-know/ Tradução nossa. Acesso em 12/10/2018)

20. O uso de microchip em pessoas no intuito de identificá-las às bases de dados demonstra o agravamento do controle social. Maiores informações, ver em: https://exame.abril.com.br/tecnologia/empresa-belga-chamaatencao-por-implantar-chips-em-funcionarios/\# (Tradução nossa. Acesso em 16/10/2018) 
Obviamente que este debate sobre a IA [Inteligência Artificial] também se caracteriza por um materialismo flagrantemente vulgar. $\mathrm{O}$ crítico francês do transhumanismo, Jean-Michel Besnier, comentou: "A deflação semântica do termo inteligência é em si mesma um sintoma, a saber, o esmorecimento, ou, se se quiser, uma simplificação preocupante da ideia que o ser humano faz de si mesmo." Historicamente, a simples ideia de inteligência artificial surgiu na sequência da disciplina da fábrica, quando o ser humano foi obrigado pelo capitalismo a ser uma máquina. Por exemplo, Emil Post (junto com Alan Turing, um dos pioneiros teóricos do computador) costumava chamar a um trabalhador de linha de montagem de "o modelo de uma máquina programável." (KONICZ. T. p. 12. 2018. Grifo nosso)

Feita esta digressão, podemos retomar a especificidade da questão que orientou nossa investigação até aqui. As razões para este procedimento adotado estão devidamente a mostra, pois elas se mostraram compatíveis com o teor mesmo do debate entre Adorno e Benjamin sob dois aspectos principais. O primeiro deles se refere a polêmica de Adorno com Benjamin a respeito de seu ensaio; "A obra de arte na era de sua reprodutibilidade técnica", publicada em 1936.

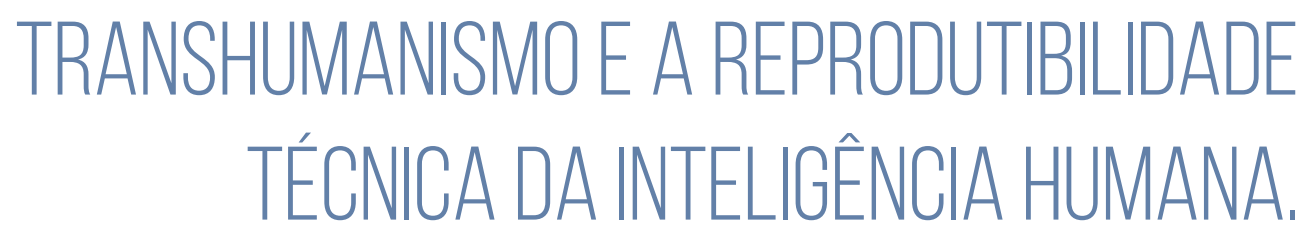

Em resumo, Benjamin acreditava que a reprodutibilidade era um processo interligado por duas nuances, digamos. Por um lado, ela progredia na medida em que atrofiava o que denominou de aura; por outro lado, essa atrofia contribuiria para a formação de uma nova sensibilidade, a qual Benjamin acreditara ser adequada às tarefas revolucionárias pelo presente momento histórico no qual participara. Em segundo lugar, a questão da aura era encarada por Adorno de maneira semelhante a questão do mito na Dialética do esclarecimento, como no "conceito de esclarecimento", ou da noção acerca do domínio da natureza, onde a aura era pensada como uma relação envolvendo sociedade e natureza, quando Adorno tratou a questão do "mana" nos antigos. Mas em obra anterior intitulada: "O conceito de história natural", de 1932, Adorno trata a questão do conceito de natureza que nos servirá como ponte entre ambas questões.

[...] se eu quisesse traduzi-lo na linguagem conceitual filosófica mais habitual, poderia caracterizá-lo mais facilmente pelo conceito de mítico. [...]. Por ele (mítico) se entende o que está aí desde sempre, o que sustenta a história humana e nela aparece como um ser anteriormente dado, submetido inexoravelmente, o que nela há de substancial. (ADORNO. T. 1996, p. 345.) 
É a partir destas reflexões sobre o "conceito de natureza" que se apresentará na Dialética do esclarecimento a questão do "mana"; quando analisaram a relação e experiência do sagrado para os antigos, portanto, havendo uma nítida relação entre ambos.

\begin{abstract}
Primário, indiferenciado, ele é tudo o que é desconhecido, estranho: aquilo que transcende o âmbito da experiência, aquilo que nas coisas é mais do que sua realidade já conhecida. O que o primitivo aí sente como algo de sobrenatural não é uma substância espiritual oposta à substância material, mas o emaranhado da natureza em face do elemento individual. [...]. Quando uma árvore é considerada não mais simplesmente como árvore, mas como testemunho de uma outra coisa, como sede do mana, a linguagem exprime a contradição de que uma coisa seria ao mesmo tempo ela mesma e outra coisa diferente dela, idêntica e não idêntica. (ADORNO \& HORKHEIMER. 1994. p. 24. Grifo nosso)
\end{abstract}

Enquanto que Benjamin, ao considerar a questão da aura, salienta que esta

[...]. É uma figura singular, composta de elementos espaciais e temporais: a aparição única de uma coisa distante, por mais perto que ela esteja. Observar, em repouso, numa tarde de verão, uma cadeia de montanhas no horizonte, ou um galho, que projeta sua sombra sobre nós, significa respirar a aura dessas montanhas, desse galho. (BENJAMIN. W. 1993. p. 170. Grifo nosso)

Pois bem, isto que se encontra em repouso e que projeta sua sombra sobre nós, que faz com que uma coisa continue distante por mais próxima que esteja, é precisamente o sagrado de que falaram Adorno \& Horkheimer, em citação anterior. Referem-se à transcendência da natureza, mas simultaneamente, se manifestaria na forma do poder dominador que prolonga a natureza no interior da sociedade, isto é

\begin{abstract}
Os processos naturais recorrentes e eternamente iguais são inculcados como ritmo do trabalho nos homens submetidos, seja por tribos estrangeiras, seja pelas próprias cliques de governantes, no compasso da maça e do porrete que ecoa em todo tambor bárbaro, em todo ritual monótono. Os símbolos assumem a expressão do fetiche. A repetição da natureza, que é o seu significado, acaba sempre por se mostrar como a permanência, por eles representada, da coerção social. O sentimento de horror materializado numa imagem sólida torna-se o sinal da dominação consolidada dos privilegiados. (ADORNO \& HORKHEIMER. 1994. p. 29. Grifo nosso)
\end{abstract}

Tendo estas questões em mente, é interessante notar que o transhumanismo, em sua acepção mais geral, portanto, advogue precisamente esta transcendência da natureza através da técnica. Elencamos no início de nossa investigação alguns destes problemas, quando tratamos da filosofia transhumanista, especialmente no que diz respeito aos ensaios futuristas com relação a fusão dos humanos com as máquinas, que vem contando, todavia, com um investimento massivo da parte da burguesia que chamamos de high tech. Isto ficou claro, dentre outras coisas, quando 
mencionamos Zoltan Istan, que concorreu ao governo da Califórnia, em 2016, como dissemos, que disse ser o transhumanismo, em suas palavras; "um campo radical da ciência que objetiva transformar os humanos, por falta de melhor termo, em deuses. " Tudo bem que esta declaração apresente forte cariz publicitário, em que pese o esforço por deixar acertado quão poderoso é o arsenal técnico de seu país. Mas é interessante notar a inclinação da parte dos tais para aquilo que aparece contendo potencialidades; tornar os humanos libertos da natureza, através da tecnologia.

Recentemente se referiu sobre o assunto um dos mais ilustres físicos norteamericanos, Stephen Hawking, acerca das descobertas no âmbito da Inteligência Artificial (IA), que segundo ele, representam o "fim da humanidade". ${ }^{21}$

Podemos até mesmo admitir serem bastante sintomático que as versões destes prognósticos pessimistas, talvez digam respeito ao fato de que para Hawking, por sua vez, o capitalismo "foi longe demais". Mas é curioso que este sentimento se restrinja tão somente a um dos recursos tecnológicos inscritos atualmente na chamada Indústria 4.0 e não aos objetivos fetichistas da produção capitalista no século XXI. Mas ainda que despertem estas emoções em declarações deste tipo, é interessante a tese de fundo, segundo a qual o capital está para entrar em uma nova fase expansionista, "eliminando" seus obstáculos humanos, através da subsunção das capacidades intelectivas das pessoas.

Em contrapartida, "replicar" humanos modificados traduz que tipo de perda de aura? Isto é, na medida em que o transhumanismo pretende traduzir filosoficamente uma série de inovações tecnológicas radicalmente possíveis no presente século, porém, sem fazer um exame crítico de suas funções no marco do capitalismo, a reprodutibilidade técnica das capacidades intelectivas das pessoas traduziria a perda da aura dessas mesmas capacidades, que por sua vez acabaria por forjar uma política transhumanista em conflito direto com o corpo humano como tal, biologicamente limitado, portanto. Por essa razão, o debate transhumanista se daria no entorno de questões essencialmente bioéticas, que, porém, não dariam conta dos investimentos de capitais promovidos pela burguesia transhumanista, que não necessariamente visam este tópico reflexivo, a julgar pela modalidade com que está se operando um reordenamento das esferas de controle, precisamente dos humanos "não-melhorados", por humanos "melhorados". Como então se poderia pensar a possibilidade da mais alta perda aurática; a inteligência humana?

[...]. Convém retomar aqui o que Walter Benjamin dizia da obra de arte na era de sua reprodutibilidade técnica. O que está perdido na obra serialmente reproduzida é sua

21. “O desenvolvimento da inteligência artificial completa poderia significar o fim da raça humana. [...] Não podemos saber exatamente o que acontecerá se uma máquina exceder nossa própria inteligência, por isso não podemos saber se seremos infinitamente ajudados por ela, ou ignorados por ela e marginalizados, ou concebivelmente destruídos por ela. " In: https://www.bbc.com/news/ technology-30290540 (Tradução nossa). Acesso em 10/10/2018 
aura, essa qualidade singular do aqui e agora, sua forma estética, e toma, segundo Benjamin, em seu destino inelutável de reprodução, uma forma política. O que está perdido é o original, que só uma história nostálgica e retrospectiva pode reconstituir como "autêntico". A forma mais avançada, mais moderna, desse desenvolvimento, que ele descrevia no cinema, na foto e na mídia contemporâneos, é aquela em que o original já não acontece, visto que as coisas são, de saída, concebidas em função de sua reprodução ilimitada. (BAUDRILLARD. J. 1990. p. 126. Grifo nosso)

Exemplos como este pretendem tão somente salientar a dificuldade teórica posta no exame das tendências tecnológicas do futuro, por mais que tenhamos diversos motivos para especular a respeito de outros dos efeitos esperados para as relações humanas no marco do desenvolvimento da Inteligência Artificial (IA). Como por exemplo, a própria composição musical, produzida por este recurso tecnológico com perfeição, que promete substituir este talento humano, e com isto, libertar o sujeito para o exercício pleno de suas capacidades? Processos com os quais certamente poderiam trazer consigo motivos mais realistas no trato de suas consequências, ${ }^{22}$ a julgar pela forma como pensara Adorno.

De momento, pensemos a forma com que Benjamin analisara o que chamou de "atrofia da aura", através da extensão da reprodutibilidade técnica da própria arte. Este autor acreditara haver uma ruptura qualitativa da experiência estética em toda a história da humanidade, representada por dois aspectos que, segundo ele, se confrontavam na obra de arte moderna; seriam o valor de culto e o valor de exposição.

Pode-se dizer que a esfera do valor de culto se articulava às práticas rituais de outrora, onde o objeto artístico reservava certo valor com o qual não era permitida sua exposição. Segundo Benjamim, em linhas gerais, a reprodutibilidade técnica representava a ruptura nesta trajetória, pela razão do grau de exposição conquistada nesta reprodutibilidade, fazendo com que a obra de arte se aproximasse das pessoas, rompendo aquela aura própria dos períodos históricos pré-capitalistas. Ao mesmo tempo, a obra de arte se colocava a si própria como atividade produtiva, pelo fato de tornar possível determinadas experiências estéticas que até então não eram possíveis. Com efeito, a ideia de obra de arte original, seu valor de culto, portanto, permaneceria fortemente abalada

22. O objetivo da máquina não é fazer uma melodia original, mas sim gerar as três harmonias de apoio em torno de uma melodia fornecida. Escreve cada harmonia separadamente, com o objetivo de prever qual nota o próprio Bach escreveria, dada a nota anterior, as notas adjacentes à melodia e outras harmonias, e a batida em que a nota pousa. Sua previsão é feita observando o que Bach fez em situações semelhantes, os 352 corais usados para treinar a IA. Maiores informações, ver em: https:// qz.com/864199/you-probably-cant-tell-the-difference-between-bach-and-music-written-by-ai-in-his-stylel $\mathrm{O}$ aplicativo Jukedeck que permite a composição musical de qualquer pessoa, através da Inteligência Artificial inscrita no mesmo e disponível online e grátis; https://www.jukedeck.com/?no-redirect=true (Acessados em 07/10/2018) Até que ponto tal dispositivo se torna funcional para o fetiche da música e a regressão da audição é uma questão importante. 
em virtude desta reprodução técnica, para a qual comprometeria a existência da aura ritualística de outrora. A pergunta é; estamos atravessando no século XXI um novo salto qualitativo nessa reprodutibilidade técnica das expressões estéticas, vocalizadas por algumas das vertentes transhumanistas hodiernas ${ }^{23}$

Este ponto é importante, pois se encontra logo no $1^{\circ}$ item da "Declaração Transhumanista" feita por Nick Bostrom e consortes, em março de 2009, que aponta precisamente na direção de grandes mudanças perceptivas, cito;

A humanidade será afetada profundamente pela ciência e tecnologia no futuro. Prevemos a possibilidade de ampliar o potencial humano através da superação do envelhecimento, os curtos-circuitos cognitivos, o sofrimento involuntário e nosso confinamento no planeta terra. (BOSTROM. N. 2011. p. 186. Tradução nossa)

Não entraremos propriamente na dimensão da sensibilidade estética própria do cinema, que segundo Benjamim, era distinta da sensibilidade burguesa, em razão de sua apreensão coletiva como parte da mudança de hábitos das massas correspondentes a revolução. Por exemplo, o fato de já estarem sendo feitos filmes totalmente editados pela Inteligência Artificial, como o caso de dois filmes recentemente lançados; Morgan e Sunspring ${ }^{24}$. Não parece difícil imaginar algo dessa natureza impactando fortemente a literatura, ainda que os transhumanistas, no geral, não toquem neste ponto.

A 20th Century Fox fez uma parceria com a IBM para lançar o primeiro trailer de filme feito integralmente por uma inteligência artificial. Utilizando o supercomputador Watson, o estúdio e a empresa de tecnologia criaram um trailer para "Morgan", Thriller que tem como principal foco uma AI. Para fazer o vídeo, Watson analisou todas as cenas do filme, selecionou seus momentos preferidos baseado em seus cálculos de gosto, que também rendeu uma lista de bônus. 25

23. Caso da primeira obra de arte criada por Inteligência Artificial; $h$ ttps://canaltech.com.br/arte/obrade-arte-criada-por-inteligencia-artificial-sera-leiloada-pela-primeira-vez-121052/ (Acesso em 18/10/2018)

24. "Visto de maneira isolada, Sunspring poderia parecer somente uma ficção científica de baixo orçamento [...] No entanto, o curta-metragem se mostra um tanto revolucionário ao se tornar a primeira produção do tipo totalmente escrita por uma inteligência artificial - que aparece nos créditos com o nome "Benjamin", escolhido por ela mesma. [...] "Assim que fizemos a primeira leitura [do texto], todos ao redor da mesa ficaram rindo com contentamento", afirmou Sharp ao site Ars Technica. Os atores tiveram seus papéis atribuídos aleatoriamente e escolheram o tom de suas falas (e suas expressões corporais) conforme liam o roteiro. [...] Benjamin também foi o responsável pela produção da música-tema, que foi produzida a partir de um banco de dados contendo $30 \mathrm{mil}$ canções populares. O resultado foi aprovado pelos jurados do festival, que destacaram Sunspring como uma das melhores produções participantes do desafio de 48 horas.". Fonte: https://www. tecmundo.com.br/inteligencia-artificial/106514-assista-primeiro-filme-escrito-inteligencia-artificial.htm (Acesso em 19/10/2018)

25. Maiores informações, ver em: https://adrenaline.uol.com.br/2016/09/02/45501/filme-morgan-ganhatrailer-feito-integralmente-por-inteligencia-artificial-ibm-watson/ (Acesso em 19/10/2018) 
Bem, Adorno e Benjamin discutem suas discordâncias a respeito destas questões em cartas que trocaram neste período. Mas a resposta mais direta e desenvolvida de Adorno encontra-se no ensaio: "O fetichismo na música e a regressão da audição". Em lugar de uma atrofia da aura, expansão da reificação; em lugar da sensibilidade revolucionária, regressão da audição. Para Adorno, o traço principal da questão, estaria no fato de que a segunda natureza constituída pelo capital se adensava e cristalizava, movida pela expansão do fetiche, contando, para isso, com recursos novos e cada vez mais poderosos.

Este debate se revela atual, como podemos observar perante o que já dissemos. Consequentemente, o debate acerca da superação das capacidades humanas conta com diversos recursos tecnológicos que regimentam tais discussões, sem as quais o próprio debate permaneceria inócuo. Como efeito, parece-nos mais coerente examinarmos tais dispositivos sobre a ótica de seus patrocinadores, os quais conhecemos bem. Afinal, investem para poderem personificar os resultados e extraírem possíveis retornos lucrativos na fermentação de uma eugenia em curso?

Alguns dos exemplos que foram elencados ao longo do texto pretenderam ratificar as tendências de reordenamento das esferas de controle social hierárquico, que pode muito bem se dar entre "humanos normais" e "humanos melhorados"; motivada pela amplitude das possiblidades do Big Data e da Inteligência Artificial no marco das relações capitalistas. De tal maneira que podemos observar que Benjamin poderia muito bem ser considerado um transhumanista democrático, se transportado para o presente contexto, dado que acreditaria ser possível a emergência de uma nova resistência política no âmbito dessa reprodutibilidade de corpos melhorados; ao passo que Adorno se inclinaria por uma crítica substantiva de expectativas dessa natureza, o que tornaria este último um bioconservador para muitos dos defensores do transhumanismo.

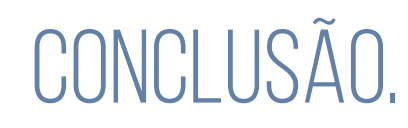

O centro do problema do transhumanismo enquanto movimento filosófico e cultural, político e social, reside no contexto histórico do qual ele é portador ou continuador. Delimitar as formas históricas precedentes, que de algum modo convergem neste fenômeno, será tarefa para outro texto. Mas uma coisa podemos dizer dentre o que pontuamos até aqui, que é o fato de que este debate só vem tendo repercussão mediante algumas das inovações tecnológicas que se apoia, as quais torna-os atuais, portanto, longe de qualquer especulação meramente futurista, como talvez pudesse ser em suas origens mais primárias, em meados da década de sessenta do século passado. 
Também por essa razão, uma análise criteriosa acerca das motivações políticas no entorno daquilo que se convencionou chamar de pós-modernidade, a partir da década de setenta do século XX poderia traduzir o transhumanismo sobre a lente tardia deste mesmo movimento, não sendo uma novidade solta no ar, mas carregado de tendências que em seu nascedouro motivaram diversas outras, não necessariamente convergentes. Um estudo acerca desta relação entre pósmodernismo e transhumanismo também ficará para outro texto.

Contudo, da síntese que podemos extrair das colocações que fizemos, consistiu em apresentar o movimento sobre a forma com que vem sendo motivado o debate. Enquanto não se coloca em consideração no debate do movimento o fato de haverem inúmeros capitalistas interessados em modificações biotecnológicas nos seres humanos, isto é, enquanto não se politizar a tecnologia mesma, permaneceremos reféns de diversas ponderações ou discursos mais ou menos entusiasmados a respeito do futuro, sem colocar em questão a lógica mesma do capital em tornar mercantilizáveis, em subordinar ao lucro e converter em fonte de exploração de mais-valor, justamente através do incremento das forças produtivas, as relações sociais entre as pessoas. De tal maneira que este artigo pretendeu apenas pincelar um estudo que faremos com maior fôlego sobre a conjuntura e a circunstância específica que o debate pós-humano ou transhumanista se coloca no cenário cultural contemporâneo, talvez como a mais avançada ideologia do capitalismo tardio.

Examinar suas raízes históricas, filosóficas e culturais, para em seguida dotá-lo da significação peculiar que lhe é comum, talvez poderá restituí-lo de sua amálgama ainda informe e lapidá-lo enquanto ideologia da burguesia high tech do vale do silício e consortes. Esperamos, com alguns dos exemplos que oferecemos, haver pontuado para estas tendências; intensificação do controle; reificação da inteligência; imortalidade cibernética; etc., em suma, o transhumanismo viria atualizar novos mitos prometéicos, dos quais deveremos encarar se quisermos entende-lo em seu devir de longo prazo.

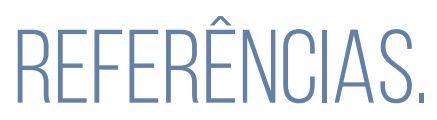

ADORNO \& HORKHEIMER. Dialética do Esclarecimento. Ed Zahar. 1994. Rio de Janeiro.

A Ideia de História Natural. Theodor W. Adorno. 1996. Tradução de Bruno Pucci. In: https://cesarmangolin.files.wordpress.com/2011/08/adorno-a-idc3a9ia-dehistc3b3ria-natural-1932-doc.doc 
ALONSO. Luis E. Echarte "Neurocosmética, Transhumanismo y Materialismo eliminativo: Hacia nuevas formas de Eugenesia". Cuaderno de Bioética. XXIII, 2012/1a . Espanha.

AYUSO, Miguel (2016a): “Operación inmortalidad: 'Me dijeron que lo hiciera en secreto, pero debe ser público'", El Confidencial. In; http://www.elconfidencial.com/almacorazonvida/2015-04-24/la-inmortalidad-es-el-sueno-de-los-nuevos-filantropos_725677/

ANTONIO. F. K. “Transhumanismo e suas oscilações prometeico-fáusticas: Tecnoapoteose na era da ciência demiúrgica." Dissertação de Mestrado. Natal-RN. 2017

BAUDRILLARD. J. "A transparência do mal. Ensaios sobre fenômenos extremos." Ed. Papirus. Portugal. 1990.

BAILEY, Ronald 2009. "Transhumanism and the limits of democracy", Workshop on Transhumanism and the Future of Democracy. Reason.Com: Free Minds \& Free Markets. In; http://reason.com/archives/2009/04/28/transhumanism-and-the-limits-o

BOSTROM, Nick "A History of transhumanist thought", Journal of Evolution and Technology. 2005.In; http://www.nickbostrom.com/papers/history.pdf

"Una Historia del Pensamiento Transhumanista". Argumentos de Razón Técnica, $\mathrm{n}^{-1}$ 14, 2011

CARDOZO. John Jairo \& CABRERA. Tania Meneses. “Transhumanismo: concepciones, alcances y tendências." Bogotá, 2014

CRUZ. Rui Vieira. “Nanoconfigurações: Da jogabilidade à promoção de conteúdos de transhumanismo" Revista Comunicando, Vol. 5, № 2 - 2016

HUGHES, James, "The politics of transhumanism", 2001 Annual Meeting of the Society for Social Studies of Science. Institute for Ethics E Emerging Technologies: In: https://ieet. org/index.php/IEET2/more/1385

KONICZ. T. Inteligência Artificial e Capital. 2018. In; www.exitonline.org.

LAFAIETE O. Júnior “Bioconservadorismo e transhumanismo: a questão do melhoramento humano através das biotecnologias ". Dissertação de Mestrado. 2018. Uberlândia.

LIMA. Jefferson "A doutrina transhumanista como moral transcendente $\mathcal{E}$ a filosofia de Deleuze \& Guatarri como resistência ética imanente na contemporaneidade". Dissertação de Mestrado. Fortaleza. 2017

LIMA. A. L. Homero. "Do corpo-máquina ao corpo-informação: o pós-humano como horizonte biotecnológico" Tese de doutorado. Recife. 2004 
MARX. K. Grundrisse. 2011. Ed. Boitempo. São Paulo.

MEYER. T. Big Data e o novo mundo inteligente como estádio supremo do positivismo. 2018. In; www.exitonline.org.

ORTEGA. César, RICHART. Andrés, PÁRAMO. Víctor e RUÍZ. Christian "El mejoramiento humano avances, investigaciones y reflexiones éticas y Politicas." Ed. Comares. 2015 Valencia. España.

PESSINI. Leo. "Bioética, Humanismo e Pós-humanismo no Século XXI. Em busca de um novo ser humano?" 2017. Revista eclesiástica Brasileira.

VERHELST. T. "O direito à diferença. Identidades culturais e desenvolvimento." Ed. Vozes. Petrópolis. Rio de Janeiro. 